the centre of the ground floor (Fig. 2, 1), (b) a block for the Department of Chemical Technology (Fig. 2, 5), (c) a building with the main hall, reception and lecture rooms (Fig. 2, 3), (d) a large one-story building to house the heavy equipment of the Department of Mechanical Engineering and the central workshop for the whole University (Fig. 2, 2), (e) a laboratory for chemical technology (a similar building is planned for physical technology) (Fig. 2, 4), $(f)$ a building for the larger equipment for electrotechnics (Fig. 2, 6), $(g)$ a boiler-house for the central heating of the whole University (Fig. 2, 7).

The citizens of Eindhoven have helped and supported the new University in many ways. On the initiative of the Burgomsster of Eindhoven, a committee of leading citizens was formed to help the students in getting accommodation, to build hostels for them, to provide a club-house for the general student society (union building), to promote the possibilities for sport and to found a medical centre. This committer laid the basis for the Eindhoven Technological University Students Welfare Foundation, which is very active in providing the initial necessities for students, and is also stimulating the initiative of the 'freshmen' to build up a new sound student communal life.
The interest of industry in the new University was manifested by founding the Eindhoven University Fund to form a link between the industry in the Netherlands and the new University, this being regarded as of great importance to both. The main purpose of the Fund is to support the scientific work in the Technologicel University and to promote the contact of the scientific staff of the University with the technical soientific world in the Netherlands and abroad.

The friendly relationship between the Technical University of Delft and its newborn sister found expression in a helpful sharing of ideas during the preparative period and in the token gift of a silver chain of office for the Rector Magnificus of the new University.

The Technological University of Eindhoven has begun its task for the future, a very important task with great responsibilities. As H.M. Queen Juliana said in her opening address: "Technology is the modern mill-stone for our daily bread. It is a gift of God. We have to accept this gift with respect and gratitude, we will not over-estimate it in proud presumption nor abuse it by using it where it will not serve a positive purpose".

\title{
FLAMES AND INDUSTRY
}

T HE useful application of science to engineering has nowhere proved more difficult than in the sphere of combustion. In recent years, however, some progress has been made through the work of the International. Flame Research Foundation. The main activity of the Foundation has been to establish two experimental furnaces at the Royal Dutch Steelworks at Ijmuiden. These are fully instrumented for fundamental studies and are comparable in size with the smaller furnaces used industrially. One furnace consumes gas or oil and the other pulverized fuel.

The principal object of the work is to provide accurate and usable design formulæ for the types of flame employed in industrial furnaces. It is hoped that in the course of such developments some pos. sibilitios of improving current practice may be revealed. The inveatigations are, however, necessarily concerned with the properties of the flames themselves. The principles governing the transfer of heat from the flame to the work are intimately bound up with the nature of the latter, and advances in this respect must be the responsibility of the industries concerned.

The essence of the work of the Foundation lies, however, in its applicability to the needs of industry. For this reason a symposium was held recently in London, at which papers describing the Ijmuiden investigations were laid beside others from industry dealing with consequential developments. The symposium, which was sponsored by the Institute of Fuel, took place on October 9, at the Institution of Civil Engineers. The presentation of the Ijmuiden papers was presided over by Prof. O. A. Saunders; and Dr. D. T. A. Townend was in the chair for the industrial session.

The experimental methods used at Ijmuiden and the progress made in the understanding of flames were reviewed by Prof. M. W. Thring, assisted by Mr. E. H. Hubbard and Mr. A. E. Pengelly. The work has been almost entirely devoted to turbulent jet diffusion flames, in which a high-velocity jet of fuel, carried by compressed air or steam, entrains air for combustion through its own energy.

The furnaces are both in the form of a tunnel some 2 metres square in section and 6 metres long, with the flame directed along the axis. They have been made large compared with the flames to avoid impingement and to minimize other forms of interference by the furnace walls. As a result of this, recirculation of the combustion products is a prominent feature of the flow pattern. The furnaces are provided with vertical slots down each side for flame radiation measurements, and there are generous provisions for the insertion of probes for sampling, temperature measurement and other purposes. For the essential routine operations of measuring waste gas composition and temperature, paramagnetic oxygen analysers and suction pyrometers respectively are preferred. To estimate air leakage into the combustion chamber the fuel and air input must also be known. Combustion air, gaseous and liquid fuels are measured by orifice. meters and pulverized fuel by a constant-foed weighing belt. Air leakage is controlled through furnace pressure by means of conventional dampers, with the aid of draught gauges and a pressure recorder attached to the centre of the furnace roof.

Fuel-air mixing in a turbulent jet diffusion flame is primarily influenced by fuel jet momentum. This is conveniently measured as the reaction thrust on the burner, by means of a counterbalanced suspension system. Radiation from the flame is observed with a total-radiation pyrometer. Radiation and convection are differentiated with the aid of two heat flow meters, differing either in surface temperature 
or in surface emissivity. Gas velocities are measured with a Pitot tube and the information obtained used to carry out isokinetic sampling at a particular point for flame gases and unburnt solid particles. Gases are analysed in an Orsat type apparatus with Lom. chakov absorption vessels. The solid sample is analysed for moisture, volatile matter and ash by micro-methods or by a modified Fenton train for ultimate analysis. Element balances permit calculation of the proportion of fuel burnt at any stage in the flame and its comparison with the degree of mixing on one hand, and with the proportionate heat release on the other.

For gas and oil flames it is found that until about 90 per cent of the total requirement of combustion air has been consumed, relative mixing, reaction and heat release are closely similar. The processes of combustion and heat release can therefore be studied up to this point simply by examining the aerodynamics of the system. This enables aerodynamic similarity criteria to be applied to the scaling-down of industrial gas and oil-fired furnaces for experimental model studies. The similarity condition is that the burner nozzle must be replaced by an equivalent nozzle which gives the same mass flow and momentum, but with the stream density changed to that of the flame gases. At its far end, where the flame is influenced by the re-circulation and re-entrainment of the combustion products, simple similarity relations with cold models do not apply. This is also the case throughout a pulverized fuel flame, for although the combustion of the volatiles may be a rapid process, that of the solid residue is not so. In these circumstances, the physical process of air-fuel mixing is no longer rate-controlling.

The non-luminous radiation and emissivity of the combustion products can be evaluated from a knowledge of the temperature and concentrations of water vapour and carbon dioxide by established methods due to Schmidt and Hottel. Luminous radiation depends mainly upon the particles present in the flame. Emissivity has been successfully related to soot concentration and can be scaled. The soot appears at an early stage in the flame and thereafter decreases, but the laws and mechanism of its formation are not sufficiently understood. The concentration of soot and hence the luminous emissivity is, however, a function of the fraction of the flame length considered, the rate of axial mixing and the carbon-hydrogen ratio of the fuel used.

In the early part of the flame, the edges of the jet form a sheath of high-temperature products while the axis of the flame contains excess fuel at relatively low temperature. Around the hot sheath excess air and recirculated products bring about a considerable reduction in temperature. At a stage where 80100 per cent of stoichiometric air has reached the centre of the jet, the axial temperature reaches a peak of the order of $1,500-1,700^{\circ} \mathrm{C}$. The peak is raised by an increase in fuel input or jet momentum, and by pre-heating. Because a gas flame loses heat less rapidly by radiation than does an oil flame, its temperature is some $100^{\circ} \mathrm{C}$. higher throughout.

The Ijmuiden experiments cannot give direct information on the transfer of heat from the flame to the work since conditions in this phase of operations vary so widely. It is here that particular study by each industry becomes necessary. The Ijmuiden investigations have, however, shown how to control flame length, emissivity and coverage. Where there is direct impingement of the flame on the work, heat transfer by convection can be calculated as for a hot gas in contact with a surface. With a cold receiving surface, convection may be responsible for as much as 35 per cent of the total heat transfer.

The relevance of the work of the Foundation to conditions in steel furnaces was discussed by Dr. J. H. Chesters and Mr. R. Mayorcas. In the steel-making industry the Ijmuiden experiments have already stimulated a number of investigations and developments from which production has profited. Cold model experiments have revealed flow and wear patterns. The improved understanding of the mechanism of oil atomization and jet momentum which has resulted from the Ijmuiden work has been employed with great effect on production furnaces. Advantage has also been taken of the function of carbon in increasing flame emissivity, and the output rate of a full-scale furnace has recently been substantially increased by the application of the results of calculations based upon the Ijmuiden and other similar experiments.

The glass industry uses producer gas and liquidfuel flames of the turbulent jet diffusion type, and has followed the lead of the steel industry in the use of model experiments, some results of which were described by Mr. S. Krusjewski. The luminosity and solid particle radiation of producer gas flames require further study, but the findings of the Foundation and the steel industry on oil flames are applicable to similar flames in glass tanks. Special problems are to obtain good flame coverage without too much loss of access to the walls of the tank, and to limit recirculation so far as possible without exposing the furnace crown unduly to the flame gases. The theory of heat transfer from an oil flame in a glass furnace has been developed by Thring and the problem of heat transfer through the glass itself is to some extent understood in exact terms, but the part played by convection is at the moment appreciated only qualitatively.

The application to boilers was discussed by Dr. W. B. Carlson. The work at Ijmuiden on pulverized fuel flames, which is of particular interest to the boiler industry, has not yet progressed far. Some special factors have to be taken into consideration. Sufficient radiation must be available from flame and furnace to maintain stable ignition. The combustion region must be large enough and of adequate temperature to complete the combustion of the relatively slow-burning particles. This loads to very large combustion chambers, for which an unusually extensive scaling-up of model experiments is necessary. The great height of the boiler results in a large chimney effect within the furnace itself. The size of the flame causes it to become somewhat opaque to its own radiation and this results in a hot flame core from which the heat cannot readily be released. The need to avoid excessive ash deposition within the furnace dictates aerodynamic design to a large extent, and in general precludes compactness. The necessary provisions for ultimate esh retention, either by slagging or collection, still further enlarge the plant. The Ijmuiden pulverized fuel furnace has unfortunately no provision for experiments involving slagging of the ash. The cement industry, represented at the Symposium by Mr. E. Burke and Mr. G. Field, also uses pulverized fuel extensively. Heat transfer to the work would most readily be improved by increase of radiant intensity through control of 
flame length, temperature and emissivity. The proper distribution of heat transfer throughout the kiln also requires attention.

The problem in gas turbine combustion chambers, as pointed out by Prof. Saunders, is the reverse of that in industrial furnaces-that is to say, to limit the transfer of heat from the flame to the surfaces in order to avoid overheating. The small amount of information at present available suggesta that whereas the flames of the lighter fuels used are almost nonluminous, those of the heavier fuels emit considersble luminous radiation. However, the high-rate heat release type of chamber as used in erro-engine design probably minimizes radiation transfer from the flame and for this reason may find favour for industrial use.

J. H. BURGOYNE

\section{OBITUARIES}

\section{Prof. Léon W. Collet}

Prof. LÉon W. CoLIet died peacefully in his seventy-eighth year at Geneva on October 13. His health had been failing sadly of recent years. "Born with a rucksack on my back", he used to say ; and he attributed much of his latter-day troubles to previous strenuous exertion.

In his passing, British and American geologists see the end of a career largely devoted to their service; for Collet will long be remembered as an apostle, spreading the nappe theory of the Alps throughout the English-speaking world. Most of the amazing discoveries made since 1893 in regard to the structure of the Alps have been published in French or German. Moreover, as a problem in field-geology, the subject has been bewilderingly confused for outsiders by essential local detail, both geographical and stratigraphical. The findings, too, have been of such an unbelievable nature that to risk an opinion upon their veracity without special introduction and guidance might well seem foolhardy. It was this introduction and guidance that Collet delighted to furnish, by leading excursions, from 1909 onwards, by publishing his "Structure of the Alps" (1927, 1935 ) and by delivering lectures, especially those at Harvard (1928-29).

Collet's Swiss colleagues may perhaps protest that there are more fundamental reasons for gratitude. There are, for example, many original contributions towards the unravelling of the Alpine story, chief among which stands Collet's description, with Parejas, of the Jungfrau (1931). Here, indeed, we find work of first-rate goological ability, coupled of necessity with adventurous climbing. There are also his many valuable essays on physical geology and geography, among which must be reckoned his books, "Les Depóts Marins" (1908) and "Les Lacs" (1925).

It so happens that these two books bring us back to the British connexion. In 1904, immediately after taking his D.Sc. at Geneva, Collet joined the temporary, in part international, staff of the MurrayPullar Survey of the freshwater lochs of Scotlandthe Murray concerned was Sir John Murray, of Challenger fame. This often brought Collet to Edinburgh, where in two formative years he responded whole-heartedly to the spell cast by Peach and Horme; and their influence remained with him to the end of his days.

Collet at Geneva had been brought up in a die. hard school of Alpine interpretation, still struggling against the new ideas announced by Schardt in 1893; and it is remembered in Edinburgh how, during his sojourn there, he maintained in a lecture that it was possible that his teachers might yet prove correct. Soon after his return, however, to Geneva in 1906 as Privatdocent he saw with delight that the new interpretations were irresistible, and he at once joined the happy throng developing the profitable field thrown open to all-comers.

The rest must be put very briefly. During 1912-18 Collet was director of the newly established Federal Hydrographical Survey of Switzerland. During 1918-44 he occupied with great distinction the chair of geology and palæontology at his alma mater. $\mathrm{He}$ received many honours, but probably none was more highly valued than the foreign membership of the Royal Society of Edinburgh and the LL.D. bestowed on him by the University of Glasgow.

\section{E. B. BaIriey}

\section{Colonel E. E. B. Mackintosh}

Colonex E. E. B. Mackntosh, a former director of the Science Museum, South Kensington, died on November 25. He was the last of a line of distinguished Royal Engineer officers who directed the fortunes of the scientific collections at South Kensington from 1858 until 1945. $\mathrm{H} \theta$ and his predecessors, Donnelly, Festing, Abney, Ogilvie and Lyons, brought the Museum to its present fame, as one of the most visited museums in the world.

Mackintosh's contribution to this development was to encourage the organization of special temporary exhibitions, lasting for a few months each, on such subjects as "Noise Abatement", "Very Low Temperatures" and "Science in the Army". These, with their formal opening ceremonies by some public figure, at which Mackintosh was in his element, gave wide publicity to the Museum; and his friendly bonhomie gained much goodwill for the Museum among those who were in a position to support its activitios.

Emest Elliott Buckland Mackintosh was born in 1880 and was educated at Eton and the R.M.A., Woolwich, from which, in 1899 , he was commissioned in the Royel Engineers. He served in the Sudan and Egypt before taking part in the First World War in France, for which he was awarded the D.S.O. and appointed to the Legion of Honour. After a period, first in Hong Kong and then as chief engineer, Eastern Command, he was appointed director of the Science Museum in 1933. Almost immediately he became concerned with plans for the proposed new centre block of the Museum, which was to include a planetarium; but all his plans were frustrated by the Second World War and its preliminary crises. From $193 \theta$ onwards, except for a short period in 1939 and 1940 when he was commandant of the School of Military Engineering at Chatham, his energies and organizing ability were directed towards the evacuation and preservation of 